\title{
Diet and prey preferences of larval and pelagic juvenile Faroe Plateau cod (Gadus morhua)
}

\author{
Sólvá Jacobsen ${ }^{1}$ [ $\cdot$ Kristoffer Klitgaard Nielsen ${ }^{2} \cdot$ Rune Kristiansen $^{2} \cdot$ Peter Grønkjær ${ }^{2} \cdot$ Eilif Gaard $^{1}$. \\ Petur Steingrund ${ }^{1}$
}

Received: 12 December 2019 / Accepted: 16 June 2020 / Published online: 26 July 2020

(c) The Author(s) 2020

\begin{abstract}
The availability of suitable prey during the early life of fish may determine recruitment to the adult population. Since larval and juvenile feeding can be highly selective, their preferences for certain prey species and sizes should be considered when estimating the availability of prey. In this study, diet composition (and prey preferences) of 4984 (1366) Faroe Plateau cod (Gadus morhua) larvae and juveniles between 3 and $63 \mathrm{~mm}$ sampled on the central Faroe shelf $\left(62^{\circ} \mathrm{N}, 6.8^{\circ} \mathrm{W}\right)$ over an 8 -year period was investigated. Cod preyed on successively larger food items as they grew. Yolk-sac larvae consumed phytoplankton, copepod eggs and nauplii before the yolk sac was exhausted. Copepod eggs followed by calanoid nauplii were the predominant and preferred food items in the early larval stage. In the late larval stage these were replaced by small to medium sized (0.6-1.2 mm) copepod species mainly Pseudocalanus sp., Acartia sp. and early stage Calanus finmarchicus, of which the two former species appeared most preferred. Temora longicornis was highly abundant in juvenile cod, but the preference for this species was neutral. Positive selection and high abundance of late stage $(\geq 1.5 \mathrm{~mm})$ C. finmarchicus was observed in early juveniles, but $C$. finmarchicus was replaced by decapod larvae in late juveniles. Other abundant prey species such as Oithona sp. and barnacle larvae occurred in varying numbers in the guts, but were generally not positively selected at any stage. Late larval and early juvenile cod appeared to suffer from unfavourable feeding conditions as they fed on smaller prey than what they prefer potentially indicating bottle necks in the feeding at these development stages.
\end{abstract}

\section{Introduction}

Changes in fish populations are largely driven by variability in recruitment, and fluctuations in recruitment are widely believed to be determined during the early life stages. Although recruitment may be affected by many factors during the early life stages, food availability is often considered to be a key factor affecting growth and survival of fish larvae (Hjort 1914; Anderson 1988; Cushing 1990; Leggett and Deblois 1994). Hence, much research on the feeding

Responsible Editor: S. Hamilton.

Reviewed by Undisclosed experts.

Sólvá Jacobsen

solvaj@hav.fo

1 Faroe Marine Research Institute, Nóatún 1, PO Box 3051, 100 Tórshavn, Faroe Islands

2 Department of Bioscience, Aquatic Biology, Aarhus University, Ole Worms Allé 1, 8000 Aarhus C, Denmark ecology of the early life stages of fish has been initiated in a pursuit to identify potential relationships and causes for the variability in recruitment. In cod (Gadus morhua), early studies focused on the prey abundance and timing of prey production in order to explain the variability, but more recent studies have highlighted the importance of prey quality e.g. species and size composition (e.g. Beaugrand et al. 2003; Robert et al. 2011; Swalethorp et al. 2014).

The early life stages of cod are very opportunistic and adaptive in relation to variability in prey abundance, species composition and size distribution (Heath and Lough 2007), although gape size is a major constraint (Munk 1997). Moreover, larvae reared on only one size class of prey eventually grow to a point where the metabolic cost of search and capture exceeds the calorific value of individual prey items, and growth and survival are hence compromised (Folkvord et al. 1994). Therefore, to optimize energy input cod larvae and juveniles undergo a gradual shift in selecting progressively larger prey during ontogeny. The general feeding pattern of pelagic cod through ontogenetic development is: copepod eggs $\rightarrow$ calanoid nauplii $\rightarrow$ copepods $\rightarrow$ malacostraca (Heath 
and Lough 2007) (Fig. 1). However, some prey items are clearly preferred over others both with respect to species and size (e.g. Beaugrand et al. 2003; Buckley and Durbin 2006). Munk (1997) found larval and pelagic cod juveniles to prefer prey about $5 \%$ their own size. Yet, large prey often have better predator avoidance capabilities than small prey, and thus at some point metabolic cost can supersede the energy return from pursuing increasingly larger prey. Consequently, especially at low prey abundances cod may predate on less preferred prey that are more easily attainable (Seljeset et al. 2010). A lack of specific prey sizes and prey types may compromise growth and survival at any point during the early development of a cohort of cod. For North Sea juvenile cod a significant decrease in the mean size of prey together with changed seasonal timing and abundance of key prey has likely contributed to a reduction in growth, survival and recruitment to the adult population (Beaugrand et al. 2003). As prey abundances vary in time and space, an assessment of the general diet and prey selectivity is essential for improved understanding of the early life history of cod.

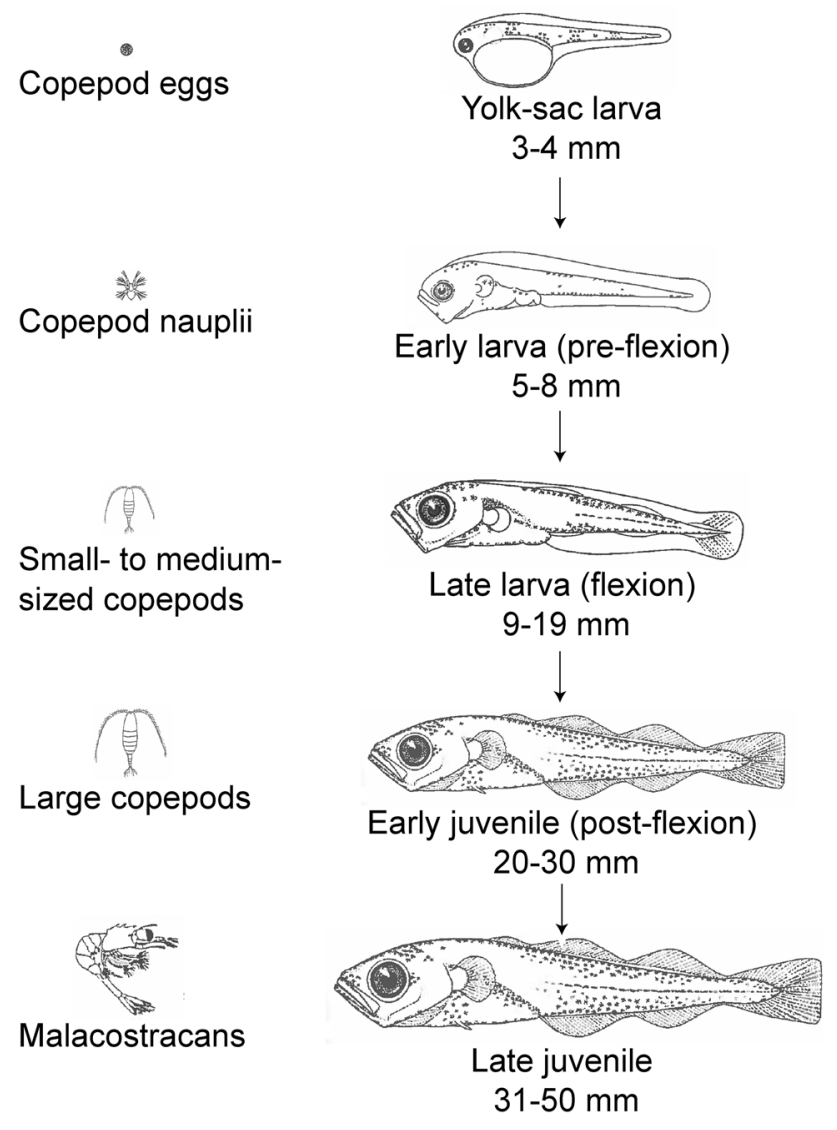

Fig. 1 Simplified schematic representation of prey for pelagic cod during ontogenetic development. Illustrations of zooplankton and cod are from Castellani and Edwards (2017) and Munk and Nielsen (2005), respectively
Faroe Plateau cod is historically the most important commercial fish species on the Faroe shelf. Assessments based on annual surveys have revealed large inter-annual variations in the recruitment of age 2 cod (Steingrund et al. 2010), which partly appears to be determined at the pelagic larval stage (Jákupsstovu and Reinert 1994; Steingrund et al. 2010). A few studies have examined the feeding of larval and pelagic cod on the Faroe shelf (Gaard and Steingrund 2001; Gaard and Reinert 2002); however, main questions such as prey species and prey size preferences of the Faroe Plateau cod remain largely unresolved.

In the present study, detailed information is presented from a comprehensive dataset on the diet composition and prey selection at different length-classes of cod larvae and juveniles on the Faroe shelf. The study is based on material sampled during the years 1998-2005 on two recurrent cruises covering the shelf: one placed in the last week of April and the other placed in the second half of June. The aim of the study was to explore the general feeding ecology of larval and pelagic juvenile cod on the Faroe shelf including prey size and prey species preferences and to identify main prey items in terms of mass and abundance. We hypothesize that the diet composition and prey preferences change with ontogeny in the larvae and pelagic juveniles and that specific prey species and sizes are preferred and hence are more important than others. Finally, we discuss whether feeding conditions during the larval and pelagic juvenile stage potentially influence the annual variability in Faroe Plateau cod 0-group abundance indices.

\section{Materials and methods}

\section{Data collection}

The samples were collected with R/V Magnus Heinason on annual standard cruises during the last week of April (hereafter termed April) 1998-2005 (except 2002) and the second half of June (hereafter termed June) 2000-2005 on the Faroe shelf (Fig. 2, Table 1). Sampling was carried out between 6:30 and 18:30. The sampling area covered the whole central shelf inside the $130 \mathrm{~m}$ bottom depth contour i.e. inside the shelf front (Larsen et al. 2009) (Table 1). As the sampling area is very well mixed (Larsen et al. 2008), the distribution of plankton is expected to be quite homogenous horizontally and vertically (Eliasen et al. 2017) and not markedly influenced by diel vertical migration.

In April, zooplankton, including ichthyoplankton, samples were collected with a Bongo net (diameter $0.6 \mathrm{~m}$ ) with a mesh size of $100 \mu \mathrm{m}$. The net was lowered slowly down to $50 \mathrm{~m}$ depth and up again, while the ship was towing at a forward speed of about $1.3 \mathrm{~m} \mathrm{~s}^{-1}$. Thus, the samples were collected as double oblique net hauls in the upper 


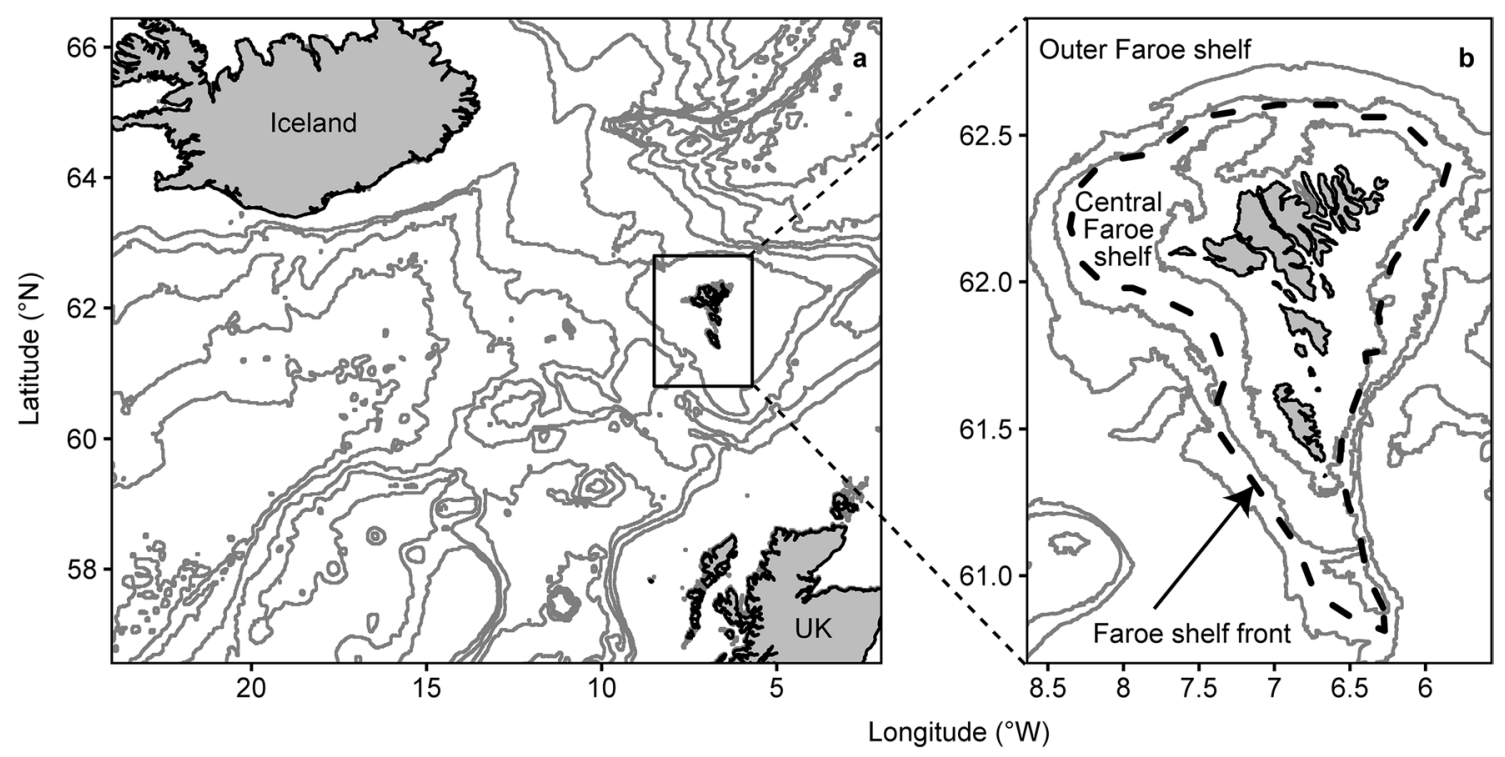

Fig. 2 a Map of the research area with bathymetry (from Pante and Simon-Bouhet 2013) and b the Faroe shelf with bathymetry (100, 150 and $200 \mathrm{~m}$ ) and the average position of the shelf front (dashed line) (Larsen et al. 2009). All samples discussed in the text were collected inside the dashed line i.e. in the central Faroe shelf
Table 1 Sampling dates and data collection summary

\begin{tabular}{lcccccc}
\hline Sampling dates & No. of fish & $\begin{array}{l}\text { No. of } \\
\text { trawl sta- } \\
\text { tions }\end{array}$ & $\begin{array}{l}\text { No. of zooplank- } \\
\text { ton stations }\end{array}$ & $\begin{array}{l}\text { Average } \\
\text { depth }(\mathrm{m})\end{array}$ & $\begin{array}{l}\text { Min. depth } \\
(\mathrm{m})\end{array}$ & $\begin{array}{l}\text { Max. depth } \\
(\mathrm{m})\end{array}$ \\
\hline April 17-24, 1998 & 1035 & 22 & 7 & 92 & 49 & 117 \\
April 23-27, 1999 & 481 & 15 & 6 & 100 & 84 & 118 \\
April 28-30, 2000 & 185 & 7 & 6 & 97 & 76 & 115 \\
June 23-30, 2000 & 248 & 18 & 11 & 91 & 68 & 124 \\
April 20-22, 2001 & 520 & 13 & 5 & 94 & 60 & 116 \\
June 22-28, 2001 & 171 & 11 & 7 & 85 & 73 & 120 \\
June 21-29, 2002 & 265 & 18 & 9 & 93 & 63 & 125 \\
April 25-28, 2003 & 321 & 8 & 6 & 99 & 80 & 122 \\
June 21-26, 2003 & 213 & 14 & 12 & 88 & 63 & 125 \\
April 20-26, 2004 & 372 & 19 & 6 & 95 & 58 & 122 \\
June 18-25, 2004 & 217 & 11 & 13 & 90 & 71 & 116 \\
April 15-25, 2005 & 720 & 24 & 20 & 96 & 62 & 128 \\
June 24-July 2, 2005 & 236 & 20 & 12 & 92 & 63 & 125 \\
\hline
\end{tabular}

$50 \mathrm{~m}$. The volume of the filtered water was measured with a Hydro-Bios flow meter mounted on the nets openings. The samples were preserved in $4 \%$ formaldehyde.

In June, zooplankton was collected with vertical hauls from $50 \mathrm{~m}$ depth to the surface. A WP-2 ring net with a mesh size of $200 \mu \mathrm{m}$ was used and the towing speed was $0.3-0.5 \mathrm{~m} \mathrm{~s}^{-1}$. Fish larvae/juveniles were collected with a pelagic trawl with $5 \mathrm{~mm}$ mesh size and a mouth opening of about $8 \mathrm{~m}$ (horizontally) times 4-5 m (vertically). The trawling depth was approximately 30-40 m; the exact depth chosen was based on the recordings on the echo-sounder. The towing speed was $1.5 \mathrm{~m} \mathrm{~s}^{-1}$ and the duration of each haul was $30 \mathrm{~min}$.

\section{Sample handling}

Zooplankton samples were rinsed of formaldehyde and split with a Motoda splitter until a subsample of at least 200 individuals were left for identification, enumeration and length measurement. For copepodites, prosome length was measured, while for decapod larvae, barnacle larvae (mainly nauplii) and calanoid nauplii carapace length was 
measured. Dry weight of the zooplankton was estimated based on length-weight relationships derived from the literature (Table 2).

A random subset of cod larvae and juveniles were standard length measured to the nearest $\mathrm{mm}$. No correction for shrinkage due to fixation and preservation was made. Guts of the larvae were dissected with surgical needles and content was identified to the lowest taxonomic level possible and measured to the nearest $0.05 \mathrm{~mm}$. As for the zooplankton, the dry weight of prey items from the gut content was calculated from length-weight keys (Table 2). Thus, the prey weights are calculated weights when they were ingested rather than the weights of the actual gut or stomach content. In total, 4984 guts were analysed (Table 1).

\section{Data processing}

For comparison of diet, cod were divided into $2 \mathrm{~mm}$ righthand closed length classes (Fig. 3). Zooplankton and gut content data was reduced to 11 of the most common prey groups (Table 2), which both in terms of abundance and dry weight occupied $>90 \%$ of the total gut content.

To evaluate the importance of the food items we applied the index of relative importance (IRI) (Pinkas et al. 1971):

$\mathrm{IRI}=(\% N+\% V) \% F$

where $N=$ numeric frequency of prey, $V=$ weight frequency of prey and $F=$ percentage occurrence in the gut.

Selectivity analysis on prey species selection was done for 10 of the most common prey groups (everything in Table 2 aside from fish larvae), while selectivity analysis on prey lengths included the same 10 prey groups sorted into 13 right-hand closed length classes as follows: lengths $0.1-0.6 \mathrm{~mm}$ : $0.1 \mathrm{~mm}$ intervals, $0.6-1.2 \mathrm{~mm}: 0.2 \mathrm{~mm}$ intervals, $1.2-2 \mathrm{~mm}: 0.4 \mathrm{~mm}$ intervals, $2-3 \mathrm{~mm}$ : $0.5 \mathrm{~mm}$ intervals and $4-5 \mathrm{~mm}: 1 \mathrm{~mm}$ interval.

Chesson's selectivity index (Chesson 1978) was employed to analyse selectivity:

$\alpha_{i}=\left(r_{i} / p_{i}\right) / \Sigma\left(r_{i} / p_{i}\right), \quad i=[1,2, \ldots, m]$
Table 2 Length to dry weight conversion table for the 10 most common zooplankton species/ groups found in the study

\begin{tabular}{|c|c|c|c|c|}
\hline Group/species & Equation & Unit weight & Unit length & References \\
\hline Copepod eggs & $\mathrm{DW}=0.460 \mu \mathrm{g}$ ind $^{-1}$ & $\mu \mathrm{g}$ & & Hirche et al. (2001) \\
\hline Calanoid nauplii & $\mathrm{DW}=0.0173 \mathrm{~L}^{\wedge} 2.27$ & $\mathrm{mg}$ & $\mathrm{mm}$ & Hay et al. (1991) \\
\hline Barnacle larvae & $\log \mathrm{DW}=3.773(\log \mathrm{L})-9.455$ & $\mu \mathrm{g}$ & $\mu \mathrm{m}$ & Uye (1982) \\
\hline Oithona sp. & $\mathrm{DW}=2.034 \mu \mathrm{g}$ ind $^{-1}$ & $\mu \mathrm{g}$ & & Hay et al. (1991) \\
\hline Acartia sp. & $\mathrm{DW}=0.0152 \mathrm{~L}^{\wedge} 2.97$ & $\mathrm{mg}$ & $\mathrm{mm}$ & Hay et al. (1991) \\
\hline Pseudocalanus sp. & $\mathrm{DW}=0.0190 \mathrm{~L}^{\wedge} 2.73$ & $\mathrm{mg}$ & $\mathrm{mm}$ & Hay et al. (1991) \\
\hline Temora longicornis & $\mathrm{DW}=0.0313 \mathrm{~L}^{\wedge} 3.06$ & $\mathrm{mg}$ & $\mathrm{mm}$ & Hay et al. (1991) \\
\hline Calanus finmarchicus & $\mathrm{DW}=0.0154 \mathrm{~L}^{\wedge} 2.71$ & $\mathrm{mg}$ & $\mathrm{mm}$ & Hay et al. (1991) \\
\hline Decapod larvae & $\log \mathrm{DW}=-0.963+2.59 \times \log (\mathrm{CL})$ & $\mathrm{mg}$ & $\mathrm{mm}$ & Lindley (1988) \\
\hline Fish larvae & $\mathrm{DW}=0.0013 \mathrm{~L}^{\wedge} 2.9856$ & $\mathrm{mg}$ & $\mathrm{mm}$ & Gaard, pers meas \\
\hline
\end{tabular}

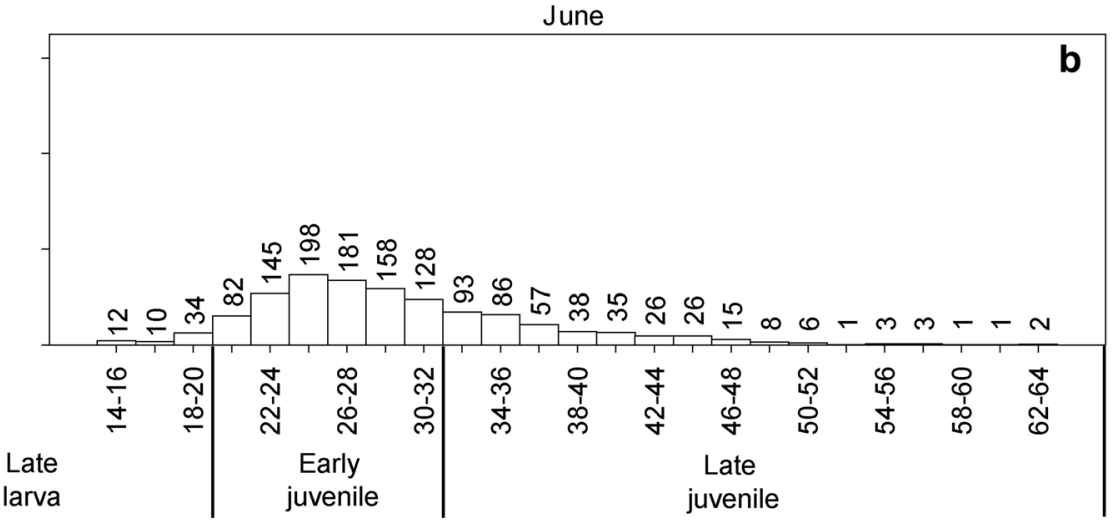

Cod length intervals $(\mathrm{mm})$

Fig. 3 Length histogram of larvae and juvenile cod selected for gut analysis in a April and b June during the years 1998-2005 together with number of observations. Vertical black lines indicate shifts in cod larvae development stages (Munk and Nielsen 2005) 
with $r_{i}=$ the proportion of food type $i$ in the diet and $p_{i}=$ the proportion of food type $i$ in the environment and $m=$ the number of food types in the environment. Selectivity values were then converted to electivity values according to Chesson (1983):

$e_{i}=\left(m \alpha_{i}-1\right) /\left[(m-2) \alpha_{i}+1\right], \quad i=[1,2, \ldots, m]$.

The electivity index ranges from -1 to +1 with a value of 0 representing neutral preference. -1 indicates complete avoidance while +1 indicates total preference. Only prey items within the size range accessible to the cod larvae (<gape size) were included in the analysis. Gape size was calculated from length-gape size relationships found in Rowlands et al. (2006).

The selectivity analysis was only done on cod sampled at stations where corresponding zooplankton data was available (Table 1). Fish with empty guts were not included in the analysis. In total, the selectivity analysis was based on gut data from 1366 cod larvae and juveniles (Table 3).

Table 3 Number of cod larvae and juveniles used in the selectivity analysis sorted by length in April and June, respectively

\begin{tabular}{|c|c|c|}
\hline \multirow[t]{2}{*}{ Fish length (mm) } & \multicolumn{2}{|c|}{$\begin{array}{l}\text { No. of } \\
\text { larvae in the } \\
\text { preference } \\
\text { analysis }\end{array}$} \\
\hline & April & June \\
\hline$<4$ & 57 & - \\
\hline $4-6$ & 665 & - \\
\hline $6-8$ & 181 & - \\
\hline $8-10$ & 44 & - \\
\hline $10-12$ & 10 & - \\
\hline $12-14$ & - & - \\
\hline $14-16$ & - & - \\
\hline $16-18$ & - & - \\
\hline $18-20$ & 1 & 5 \\
\hline $20-22$ & - & 14 \\
\hline $22-24$ & - & 41 \\
\hline $24-26$ & - & 78 \\
\hline $26-28$ & - & 76 \\
\hline $28-30$ & - & 67 \\
\hline $30-32$ & - & 49 \\
\hline $32-34$ & - & 35 \\
\hline $34-36$ & - & 17 \\
\hline $36-38$ & - & 17 \\
\hline $38-40$ & - & 5 \\
\hline $40-42$ & - & 1 \\
\hline $42-44$ & - & 2 \\
\hline $44-46$ & - & 0 \\
\hline $46-48$ & - & 1 \\
\hline Total & 958 & 408 \\
\hline
\end{tabular}

Statistical tests were performed using R (R Core Team 2018). When comparing preference values with mean values, the Welch two sample $t$ test was used. Variations in preference values were fitted using a general linear model calling the function $\mathrm{lm}$ using $\mathrm{R}$, with cod length as covariate, to test effects of prey length, prey species and the interaction of these two factors. $P$-values of 0.05 or lower were considered statistically significant.

\section{Results}

\section{Cod length}

The majority of larvae caught in April were $<10 \mathrm{~mm}$ (Fig. 3). Cod eggs were also observed on a regular basis, but these were not counted. The length distribution of cod in April was skewed to the left, with most fish in the length range 4-6 mm. The largest larva caught in April was $19 \mathrm{~mm}$. In June the length ranged from 13 to $63 \mathrm{~mm}$, although large inter-annual differences in mean length occurred (refer to Jacobsen et al. 2019).

\section{Prey environment}

The small plankton $(<0.2 \mathrm{~mm})$ was dominated by copepod eggs $(\sim 140 \mu \mathrm{m}$ in diameter and thus presumably mainly $C$. finmarchicus eggs). Calanoid and barnacle nauplii dominated in the length range $0.2-0.4 \mathrm{~mm}$, while larger plankton was mainly composed of copepodites of different species. The most abundant copepods in the length range $0.4-1 \mathrm{~mm}$ were Acartia sp. followed by Oithona sp., Pseudocalanus sp. and T. longicornis. C. finmarchicus was numerous in the length range $1-3 \mathrm{~mm}$ and generally dominated the prey biomass together with decapod larvae (Fig. 4).

\section{Diet composition}

Overall, 4190 of the 4984 analyzed cod had food in their stomach.

Of the 3634 larvae caught in April $519(\sim 14 \%)$ had yolk sac or yolk sac remnants. The amount of larvae with yolk sac decreased from $100 \%$ at a length of $3.2 \mathrm{~mm}$ to $0 \%$ at $4.7 \mathrm{~mm}$ (Fig. 5a). The number of empty guts in yolk-sac larvae decreased with increasing length (Fig. 5b). Cod larvae started feeding at a length of $3.3 \mathrm{~mm}$ (Fig. 5b). Small unidentified particles of phytoplankton origin, approximately $30 \mu \mathrm{m}$ in diameter, occurred quite frequently in the guts of small larvae, but due to their small size and fragile structure their occurrence was only noted as present or non-present (Fig. 5b). Phytoplankton was almost completely absent in larvae $>6 \mathrm{~mm}$. Occurrence of copepod eggs and calanoid nauplii increased with increasing length of the larvae with 

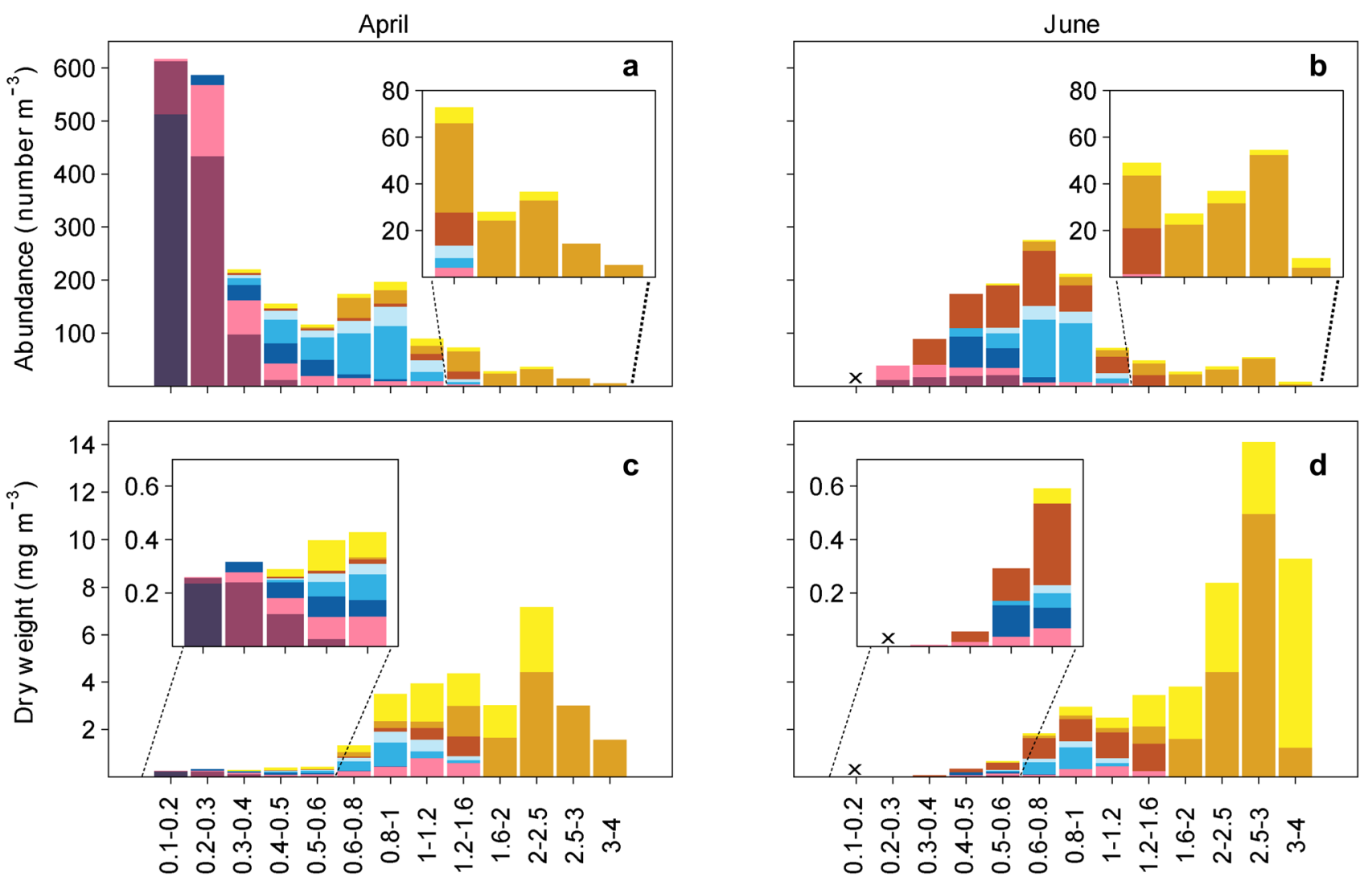

Prey length intervals $(\mathrm{mm})$

Copepod eggs

Calanoid nauplii

Barnacle larvae
Oithona sp.

Acartia sp.

Pseudocalanus sp.
T. longicornis

C. finmarchicus

Decapod larvae

Fig. 4 Mean prey in situ abundance $(\mathbf{a}, \mathbf{b})$ and dry weight $(\mathbf{c}, \mathbf{d})$ in length intervals (see Materials and methods) on the Faroe shelf in April (100$\mu \mathrm{m}$ Bongo net) and June (200- $\mu \mathrm{m}$ WP-2 net), respectively
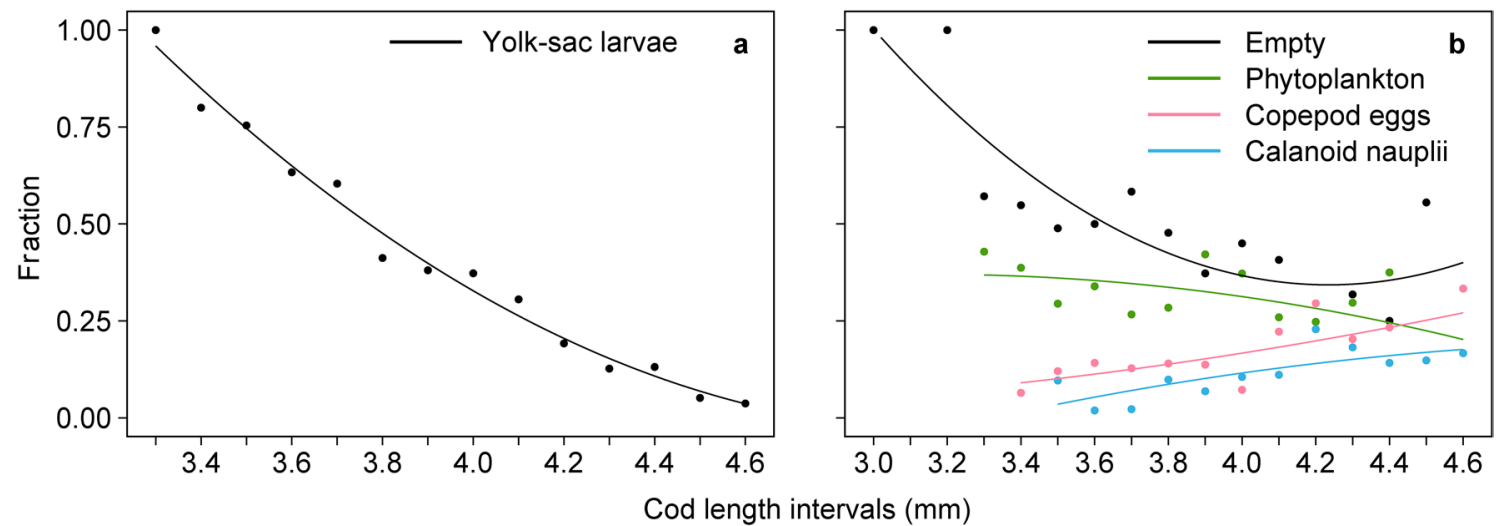

Fig. 5 a Fraction of yolk-sac larvae in relation to cod larval length and $\mathbf{b}$ occurrence of empty guts, phytoplankton, copepod eggs and calanoid nauplii in the diet of yolk-sac larvae in late April. The points show mean values at $0.1 \mathrm{~mm}$ intervals and the lines are best fit lines. $n=519$ 

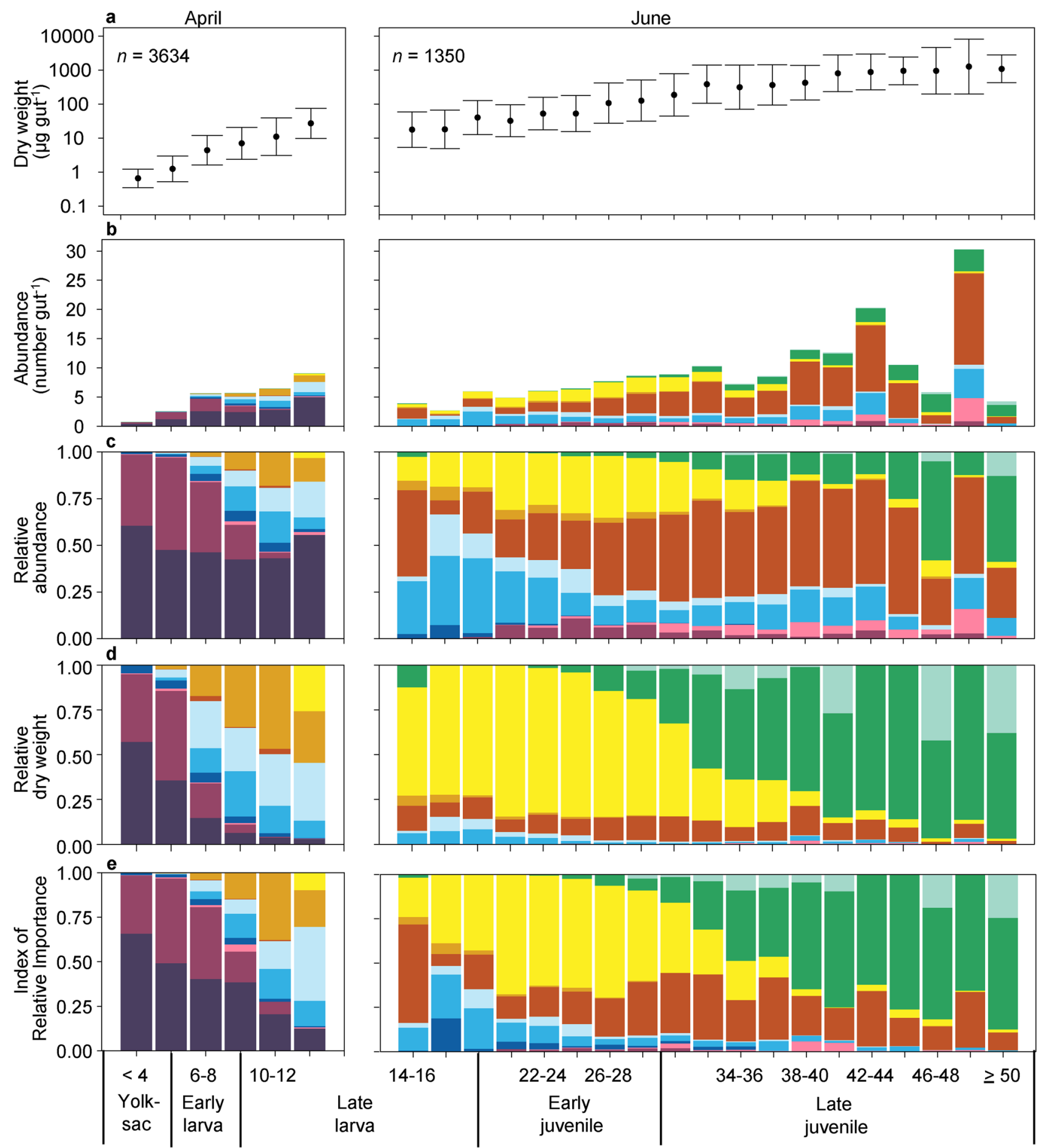

Cod length intervals $(\mathrm{mm})$
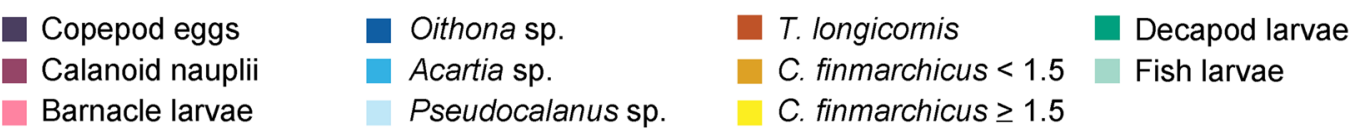

Fig. 6 Overall mean of a prey dry weight with standard deviation (note that the $y$-axis is log scaled) and $\mathbf{b}$ prey abundance and relative diet composition by $\mathbf{c}$ abundance $\mathbf{d}$ dry weight and $\mathbf{e}$ index of relative

importance. Vertical black lines indicate shifts in cod larvae development stages (refer to Fig. 3) 


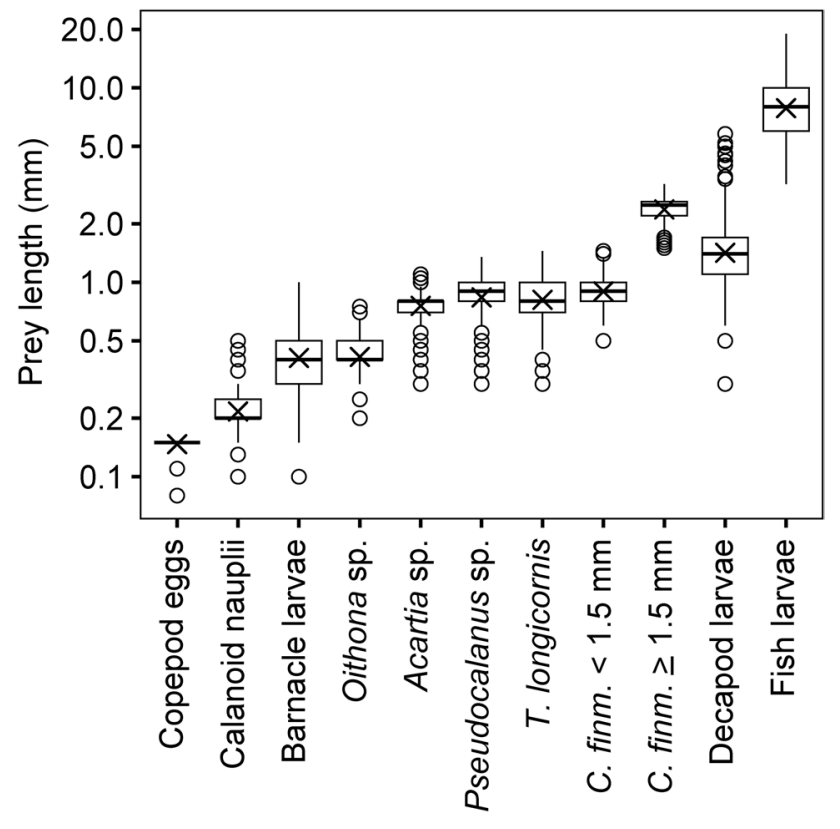

Prey group

Fig. 7 Box plot of prey sizes in the guts of cod larvae and juveniles sorted by prey group. The line in the middle of the boxes represents the median, and the left and right ends of the box are the 25 and $75 \%$ quartiles respectively. The left and right whiskers are constructed according to R's default box plot code (R Core Team 2018). Open circles (o) are outliers and the crosses (x) indicate mean lengths. Note that the $y$-axis is log scaled

yolk sac remnants (Fig. 5b). Other small prey objects found less frequently in the guts of the first feeding cod larvae were small diatoms, protozoans (e.g. ciliates), foraminifers and eggs from other invertebrates.

The mean weight of prey per gut increased with increasing cod length (Fig. 6a). The mean number of prey per gut showed the same tendency, but stagnation and even drops in mean number of prey per gut were observed at lengths of about 8, 20 and $32 \mathrm{~mm}$ (Fig. 6b) paralleling ontogenetic shifts in cod stage development (Fig. 1) and corresponding to major changes in prey species consumption i.e. shifts from copepod eggs and calanoid nauplii to small and mediumsized copepods (i.e. $<1.5 \mathrm{~mm}$ ) to late stage (i.e. $\geq 1.5 \mathrm{~mm}$ ) C. finmarchicus copepodites and finally decapod larvae (Fig. 6c-e).

The size of the different prey groups is shown in Fig. 7. The abundance of copepod eggs $\sim 0.15 \mathrm{~mm}$ in diameter, and thus presumably mainly $C$. finmarchicus eggs, increased with increasing larval length in all larvae observed in April (Fig. 6b). However, the relative contribution of copepod egg mass to the diet decreased from $>50$ to $<10 \%$ from the yolk-sac stage to the end of the early larval stage (Fig. 6d). The relative importance of copepod eggs was $>50 \%$ in yolksac larvae and $>30 \%$ in early stage larvae (Fig. 6e). The presence of calanoid nauplii with a mean carapace length of $\sim 0.2 \mathrm{~mm}$ was high in the guts of yolk-sac and early stage larvae, and dominated the prey mass in larvae 4-6 mm (Fig. 6c, d). Overall, the relative importance of calanoid nauplii in yolk-sac and early stage larvae was slightly lower than the relative importance of eggs (Fig. 6e). Barnacle larvae $\sim 0.3 \mathrm{~mm}$ and Oithona sp. $\sim 0.4 \mathrm{~mm}$ were present, but not very abundant and/or important in the guts of yolk-sac and early stage larvae. A shift towards larger prey items, mainly Acartia sp., early stage (i.e. $<1.5 \mathrm{~mm}$ ) $C$. finmarchicus and Pseudocalanus sp. copepodites with a prosome length of approximately $0.6-1.2 \mathrm{~mm}$, was observed during the transition from early larvae to the late larvae stage. Acartia sp. and Pseudocalanus sp. were present in relatively high numbers throughout the late larvae, early and late pelagic juvenile stages (Fig. 6c). The mean prey mass of Acartia sp. and Pseudocalanus sp. was particularly high (i.e. $40-50 \%$ ) in late stage larvae collected in April (Fig. 6d). Their relative importance was highest i.e. $>50 \%$ in late larvae $12-14 \mathrm{~mm}$ (Fig. 6e), while their importance was $\sim 30 \%$ in late larvae collected in June. T. longicornis $\sim 0.8 \mathrm{~mm}$ in length was highly abundant in all cod collected in June, but was rarely observed in April (Fig. 6c). The mean relative importance of T. longicornis was approximately $20 \%$ in all cod collected in June. C. finmarchicus copepodites were observed in larvae as small as $5 \mathrm{~mm}$. The mean abundance of $C$. finmarchicus increased in the fish up to the late juvenile stage and then decreased again (Fig. 6b). While the larvae caught in April almost exclusively consumed early stage (i.e. $<1.5 \mathrm{~mm}$ ) C. finmarchicus copepodites, $\sim 85 \%$ of the $C$. finmarchicus observed in cod juveniles in June were late stage copepodites (i.e. $\geq 1.5 \mathrm{~mm}$ ) with a mean length of $2.5 \mathrm{~mm}$. The relative abundance of $C$. finmarchicus was highest during the early juvenile stage ( 30\%) (Fig. 6c), while the relative mean dry weight increased steadily from $\sim 15 \%$ in early stage cod larvae to $>80 \%$ in early juveniles before declining again (Fig. 6d). Late stage $C$. finmarchicus were the most important prey item for early juvenile cod (Fig. 6e). Decapod larvae with a mean carapace length of $1.5 \mathrm{~mm}$ (mainly zoeae in the infraorders Anomura, Brachyura and Caridea) started appearing in the guts during the early juvenile period and dominated the prey biomass in late juveniles (Fig. 6d). Decapod larvae were the most important prey item for late juvenile cod (Fig. 6e). In addition, fish larvae (mainly gadoid) around $9 \mathrm{~mm}$ in length were observed on occasion in late juveniles (Fig. 6b-e).

\section{Prey size preference}

There was a clear tendency for prey preference towards larger sizes as the fish grew larger (Fig. 8a). Overall, the prey lengths of maximal preference was slightly higher 

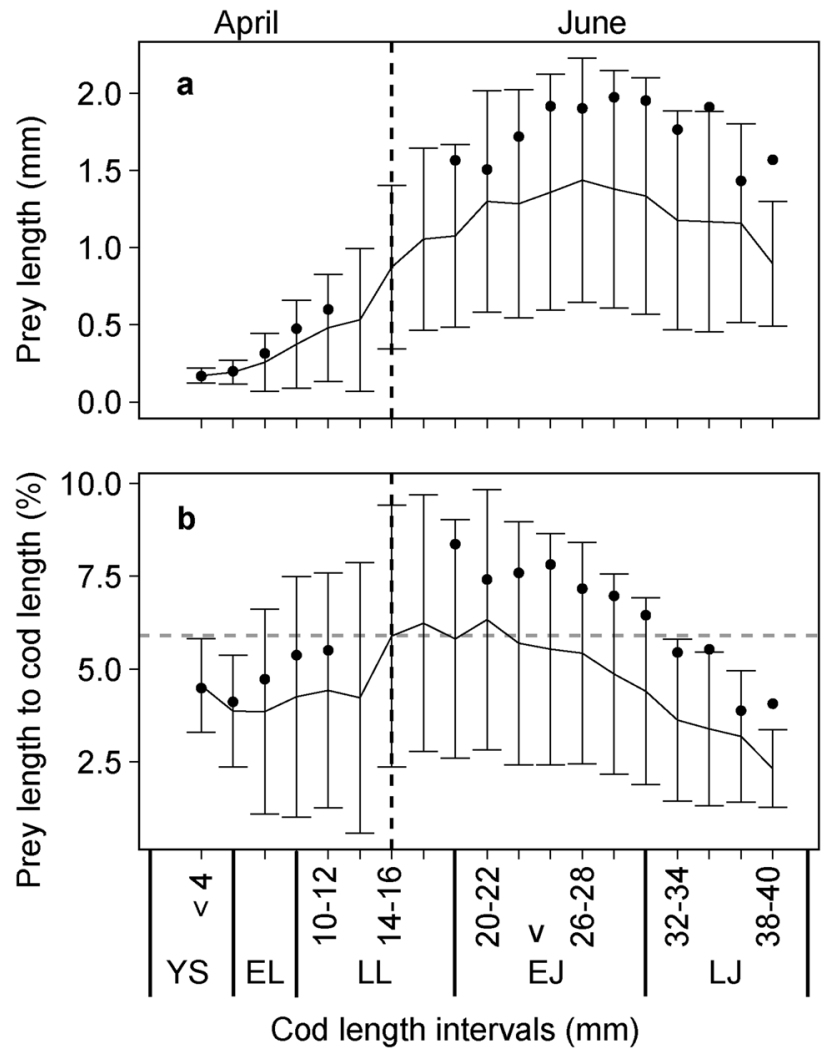

Fig. 8 Mean prey lengths with standard deviation ingested in relation to predator length and prey lengths of maximal preference (black dots (•)) (Chesson 1978). a Absolute values of prey lengths and b prey to predator length ratio (the horizontal grey dashed line indicates the overall preferred prey length relative to cod length). The vertical black dashed line separates samples collected in April $(n=958)$ from samples collected in June $(n=408)$. Vertical black lines indicate shifts in cod larvae development stages ( $Y S$ yolk-sac, $E L$ early larva, $L L$ late larva, $E J$ early juvenile, $L J$ late juvenile) (refer to Fig. 3 )

than the mean lengths of prey ingested (Fig. 8a) (Welch two sample $t$ test, $t 16=1.77, P=0.09)$. The variation in prey lengths ingested by larval and juvenile cod relative to cod length was highest in late larval and juvenile cod (Fig. 8b). The average preferred prey length relative to cod length generally increased throughout the larval phase before declining again during the juvenile phase (Fig. 8b). Overall, the preferred prey length relative to cod length was $5.9 \%$ (range $3.8-8.4 \%$ ) (Fig. 8 b). The overall mean prey length ingested relative to cod length was significantly smaller than the preferred prey length (Welch two sample $t$ test, $t 16=3.18, P<0.01)$.

\section{Prey species preference}

Yolk-sac and early larval cod had a positive preference for copepod eggs (Fig. 9a). Calanoid nauplii were also marginally positively selected in early larval cod (Fig. 9b), but to a lesser degree than copepod eggs. Barnacle larvae and Oithona sp. were generally selected against during the whole larval and juvenile period (Fig. 9c, d). Acartia sp. and Pseudocalanus sp. were increasingly preferred starting at the early larval stage and seemingly throughout the late larval stage, but appeared less important for juvenile cod (Fig. 9e-f). Unfortunately no preference data was available for cod 12-18 mm. T. longicornis and early stage (i.e. $<1.5 \mathrm{~mm}$ ) C. finmarchicus were not positively selected for at any cod length (Fig. 9g, h). However, early juvenile cod showed a clear positive preference for late stage (i.e. $\geq 1.5 \mathrm{~mm}$ ) C. finmarchicus (Fig. 9i), while decapod larvae appeared highly preferred in late juvenile cod (Fig. 9j). Since the concentration of fish larvae was low in the net samples, no preference analysis was done for this prey group.

\section{Preference for prey size and species}

Some prey species were preferred over others, even when the prey were of the same length (e.g. Pseudocalanus sp. vs. C. finmarchicus in the length range 1-1.2 mm) (Fig. 10). In addition, for most copepod groups large individuals (i.e. late stage copepodites) were generally preferred over small individuals (i.e. early stage copepodites). Overall, preference values were significantly affected by prey species and by the interaction between prey length and prey species (Linear regression, $r^{2}=0.2, F 20,18,257=225.9, P<0.001$ ) (Table 4).

\section{Discussion}

In this paper, feeding ecology of cod during the pelagic period on the Faroe shelf along with prey size and prey species preferences during ontogenetic development was investigated. Overall, the study showed that during the pelagic period cod larvae and juveniles successively feed on copepod eggs $\rightarrow$ calanoid nauplii $\rightarrow$ copepods $\rightarrow$ malacostraca (Fig. 6), and that the shifts in diet roughly correspond to major shifts in cod development (Fig. 1). Cod larvae and juveniles preferred prey about $4-8 \%$ of their own length (Fig. 8b). Thus, this study largely agrees with similar studies on the feeding ecology of cod larvae and pelagic juveniles in other areas of the North Atlantic (Kane 1984; Thorisson 1989; Fossum and Ellertsen 1994; Munk 1997; Rowlands et al. 2008; Robert et al. 2011; Swalethorp et al. 2014). The main results from the current study demonstrate that cod prefer increasingly larger prey as they grow (Fig. 8a), but that certain prey species are preferred over others (Fig. 9), even when the prey are of the same length (Fig. 10, Table 4). This suggests that other characteristics, such as prey body composition, behaviour or visibility affect their importance as prey. Furthermore, prey abundance appears to affect the 


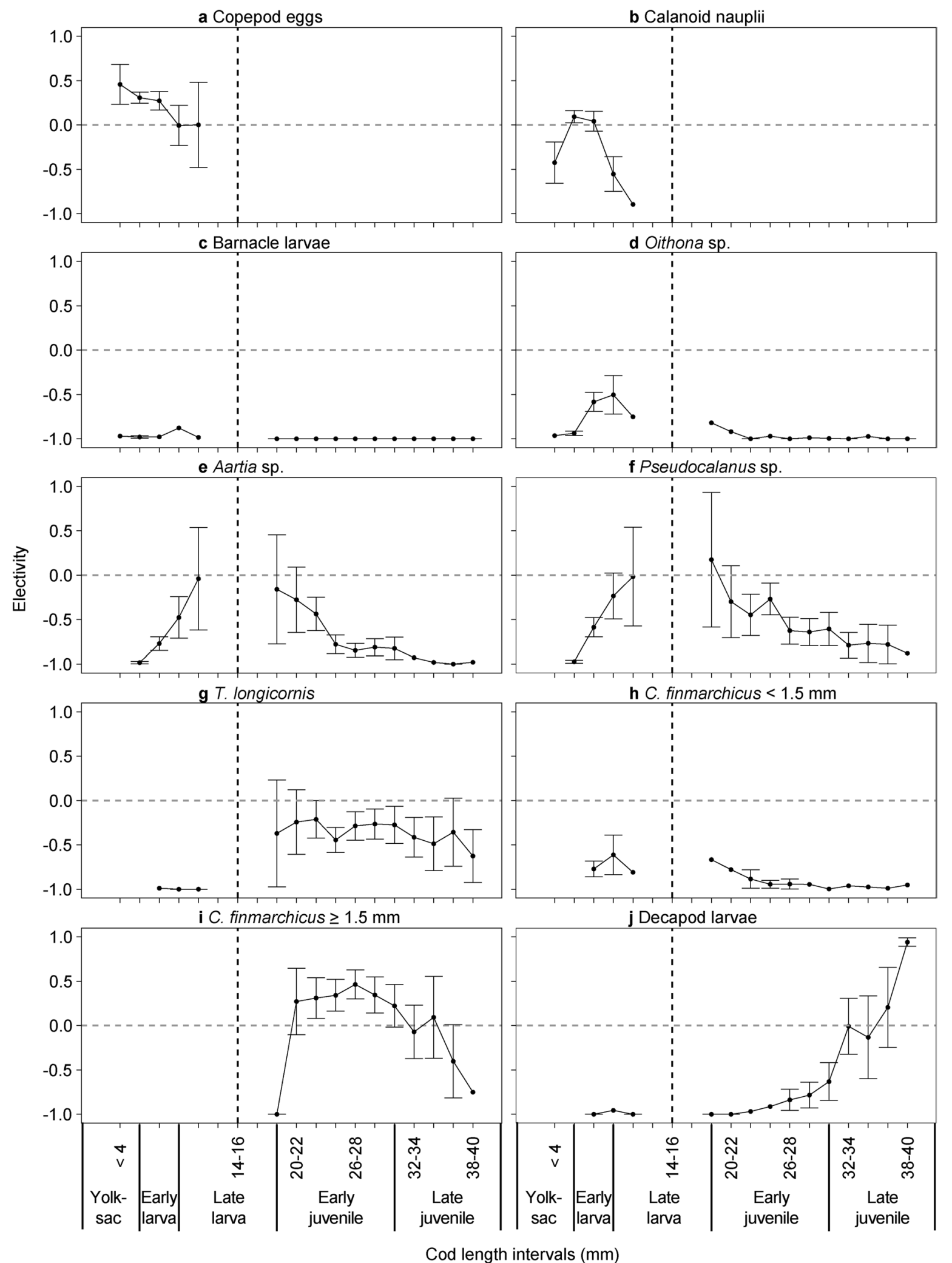

Fig. 9 Mean preference (Chesson 1983) expressed by electivity in comparison of 10 groups of prey during ontogenetic development of pelagic cod on the Faroe shelf. Error bars indicate 95\% confidence intervals around the mean. The vertical black dashed line separates samples collected in April $(n=958)$ from samples collected in June $(n=408)$. Vertical black lines indicate shifts in cod larvae development stages (refer to Fig. 3) 
feeding behaviour, but overall the preference of prey species changes with size and development of the predator. This is discussed below.

\section{Yolk-sac and early larvae}

In agreement with other studies, yolk-sac larvae captured prey before the yolk sac was exhausted and phytoplankton was quite abundant in the guts at the onset of first feeding, but was not present in larvae $>6$ mm (Fig. 5) (Kane 1984; Thompson and Harrop 1991; Fossum and Ellertsen 1994; Gaard and Steingrund 2001). While phytoplankton may provide a nutritional boost to the smallest larvae and improve first feeding capabilities (van der Meeren and Næss 1993; Overton et al. 2010), it remains unclear to which extent phytoplankton is important in the diet of cod larvae on the Faroe shelf. However, the increased occurrence of copepod eggs and calanoid nauplii among the yolk-sac larvae indicates that phytoplankton is not an adequate food source for larvae $>4$ mm (Fig. 5b).

Copepod eggs represented an essential part of the diet during the yolk-sac and early larval phase (Fig. 6). This is in agreement with another study on the first-feeding of Faroe Plateau cod (Gaard and Steingrund 2001), but stands in contrast with most studies from other areas who observe that copepod eggs are replaced by calanoid nauplii when the larvae are $\sim 6 \mathrm{~mm}$ in length (Heath and Lough 2007 and references there in). The present observations indicate that there is a lack of other suitable prey (i.e. copepod nauplii) in the environment in April. Indeed, the comparison between prey length and cod length (Fig. 8a) suggests that this may be the case as early stage larvae on average consumed smaller prey than what they normally prefer. However, the prey species preference analysis suggests that copepod eggs are a highly preferred prey in all yolk-sac and early stage larvae (Fig. 9a). But note, that the preference analysis on copepod eggs might be biased towards positive selection as a proportion of eggs may pass through the $100 \mu \mathrm{m}$ sampling net (Nichols and Thompson 1991). Calanoid nauplii, on the other hand, were only preferred in larvae 4-8 $\mathrm{mm}$ (Fig. 9b), and it appeared that nauplii in the length range $0.2-0.4 \mathrm{~mm}$ were more preferred than their smaller and larger kin, which may be due to nutritional and behavioural differences (Jung-Madsen et al. 2013; Swalethorp et al. 2014). Any which way, the high abundance of copepod eggs in yolk-sac and early stage cod larvae very likely make them an essential part of the Faroe Plateau cod larvae's diet.

The fecundity and abundance of the most common copepod species on the Faroe shelf are highly dependent on food availability (Debes et al. 2008a) i.e. the timing and intensity of the spring bloom, which rarely occurs prior to May (Debes et al. 2008b; Eliasen et al. 2017; Jacobsen et al. 2018). Hence, there is presumably a limited concentration of small prey available to cod larvae in late April. However, the copepod $C$. finmarchicus has a significant egg production fuelled by winter lipid reserves prior to the spring bloom in the Faroe shelf area (Gaard 2000; Debes et al. 2008a; Madsen et al. 2008). In fact, large-scale studies on the egg production of $C$. finmarchicus suggest that both the spring production and the spring abundance of spawning $C$. finmarchicus females is higher on the Faroe shelf than in several other adjacent areas (Richardson et al. 1999; Stenevik et al. 2007; Jónasdóttir et al. 2008). This indicates a higher abundance of copepod eggs in the Faroe area during spring compared with neighbouring areas, and may explain the relatively high proportion of copepod eggs in the guts of Faroe Plateau cod larvae in April. Furthermore, Calanus eggs are likely more nutritious than starved nauplii (JungMadsen et al. 2013). The high abundance and immobility of copepod eggs could make them more favourable as prey than calanoid nauplii.

Small nauplii of barnacles are within the suitable size for early stage larvae (Figs. 4a, 7a) and are often highly abundant on the Faroe shelf during spring (Gaard 1999; Jacobsen et al. 2018), but the current study showed that they are generally not selected by the cod larvae (Figs. 6, 9c) presumably because their frontal horns make them unsuitable as food (Fossum and Ellertsen 1994). Also Oithona sp. copepodites are small enough to be eaten by early stage cod larvae, but similar to other studies they are rarely observed among the stomach content (Fig. 6) and are not a highly preferred food item (Fig. 9d) (Kane 1984; Fossum and Ellertsen 1994; Pepin and Penney 1997; Robert et al. 2011; Swalethorp et al. 2014). These findings stress the importance of focusing on abundance of preferred prey species when assessing the actual prey availability to larval cod.

\section{The late larval period}

Late larval Faroe Plateau cod are most abundant in May, and since the present study is based on samples collected in April and June, respectively, there were relatively few larvae caught in the late larval length range (i.e. cod 9-19 mm) (Table 3). What's more, the prey field on the Faroe shelf is very likely different in May compared with April and June (Gaard 1999; Debes and Eliasen 2006). Hence, it is difficult to estimate the real prey preferences of late larval cod and future investigations are necessary to validate the conclusions that can be drawn from this study regarding cod in their late larval period. Having said that, the present results show that the medium-sized copepods Acartia sp. and Pseudocalanus $\mathrm{sp}$. in the size range $0.6-1.2 \mathrm{~mm}$ were highly important for late larvae (Fig. 6) and appeared to be the most preferred species in the intermediate range of prey sizes in late larval cod (Figs. 9, 10). Early stage $(<1.5 \mathrm{~mm})$ C. finmarchicus copepodites were also highly represented in the 

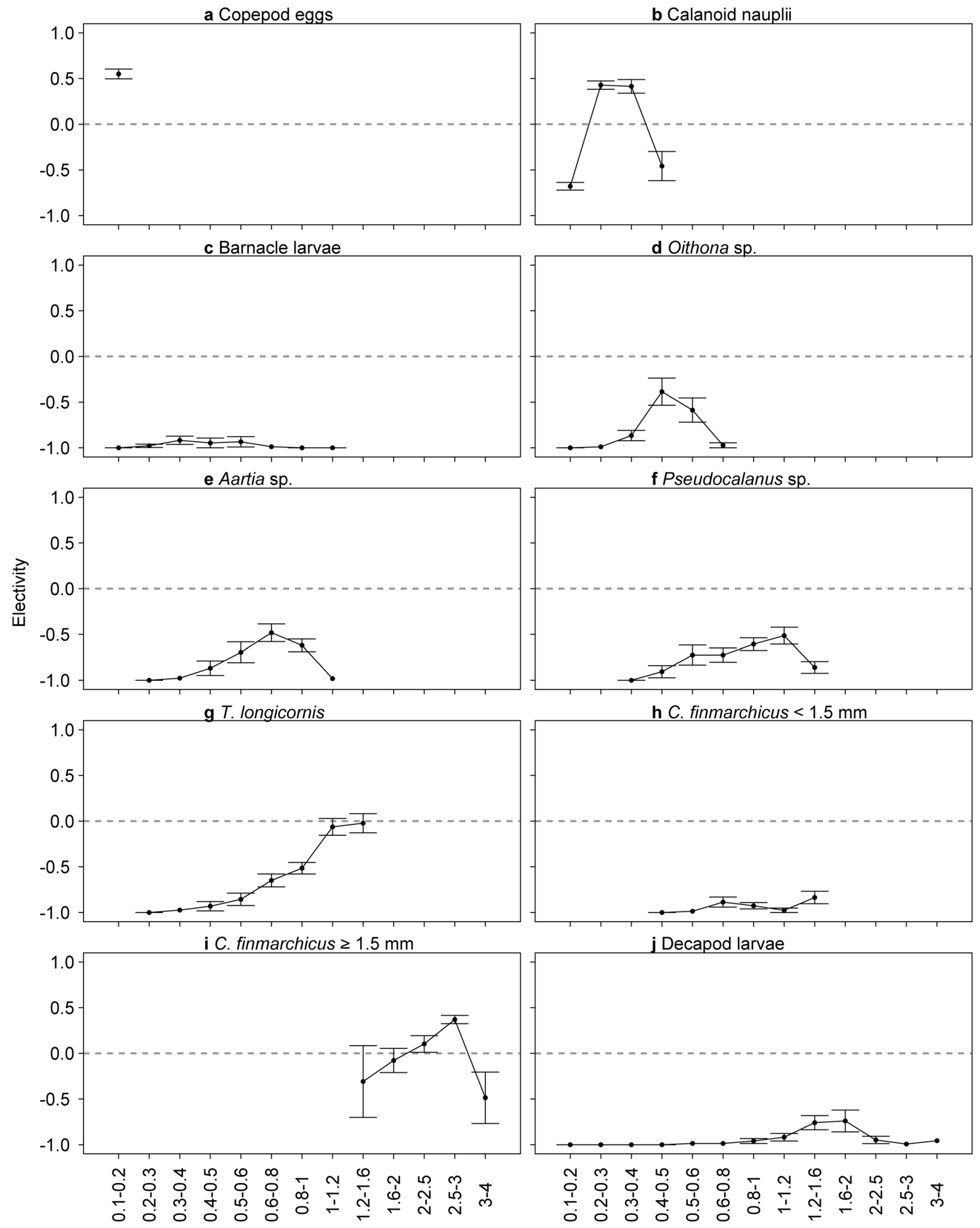

Prey length intervals $(\mathrm{mm})$

Fig. 10 Mean preference (Chesson 1983) expressed by electivity in comparison of 10 groups of prey along an axis of prey length intervals. The figure includes all cod larvae development stages. Error bars indicate $95 \%$ confidence intervals around the mean 
Table 4 Linear model test results for effects of prey length and prey species on the preference (square root of $\alpha$ ) of prey consumed by cod, accounting for cod length

\begin{tabular}{lrrrr}
\hline & Sum Sq & \multicolumn{1}{c}{ Df } & \multicolumn{1}{c}{$F$} & \multicolumn{1}{c}{$P$} \\
\hline Prey length & 0.21 & 1 & 3.06 & 0.080 \\
Prey species & 6.12 & 9 & 9.69 & $<0.001$ \\
Cod length & 95.73 & 1 & 1365.13 & $<0.001$ \\
$\begin{array}{l}\text { Prey length } \times \text { prey } \\
\quad \text { species }\end{array}$ & 23.47 & 9 & 37.18 & $<0.001$ \\
Residuals & 1280.24 & 18257 & & \\
\hline
\end{tabular}

guts of late larvae (Fig. 6), but their presence appeared more related to high abundance in the environment than to active selection by the cod (Fig. 8h). Lipid content in copepods is highest in copepodite stages IV and V (Kattner and Krause 1987; Hygum et al. 2000; Svetlichny et al. 2006), which probably explains why late larval cod prefer Pseudocalanus sp. and Acartia sp. more than early stage $C$. finmarchicus copepodites. The remaining abundant copepod in the intermediate size range in the zooplankton assemblage, $T$. longicornis, generally seemed not to be positively selected by cod in their late larval period (Fig. 9g), maybe because it has a broader body shape and thus is too large for late larval cod compared with e.g. Acartia sp. and Pseudocalanus sp., but maybe also because it was not very abundant in April (Fig. 4a) when most late larval cod were sampled. Late larvae generally ingest prey with a body width of $13 \pm 5 \%$ the mouth gape (Swalethorp et al. 2015). For a $15 \mathrm{~mm}$ larvae that is copepods with a prosome width of $0.15-0.35 \mathrm{~mm}$ which encompass all Acartia and Pseudocalanus copepodite development stages, but only Temora copepodite stages I-III (Conway 2006). The findings of the current study are generally in accordance with observations from other areas of prey selection in late larval cod. A high preference for Pseudocalanus sp. at the late larval stage is described in many cod populations across the North Atlantic (Kane 1984; Munk 1997; Rowlands et al. 2008; McLaren and Avendaño 2011; Robert et al. 2011; Swalethorp et al. 2014). Furthermore, a study on larval and pelagic juvenile Irish Sea fish shows positive selection for Acartia clausii and negative selection for T. longicornis in cod in their late larval stage (Rowlands et al. 2008).

Cod in their late larval period undergo extensive physiological and morphological changes and consequently have relatively high energy requirements, and it is at this stage that competition for food is expected to commence (Thompson and Harrop 1991). This is in line with our study which shows that it was at the late larval development stage that the change in mean prey size consumption was the largest (Fig. 8a). What's more, the variation in relative prey length to cod length was particularly high in the late larval period (Fig. 8b) possibly indicating unfavourable feeding conditions at this stage (Seljeset et al. 2010). Interestingly, the mean prey dry weight and mean prey abundance per gut in late larvae was low compared to other studies (Kane 1984; McLaren et al. 1997) indicating a rather low mean abundance of prey items suitable for late stage larvae in the environment on the Faroe shelf. The spring/early summer abundance of intermediate sized copepods, i.e. copepods $0.8-1.2 \mathrm{~mm}$, is highly dependent on the local primary production (i.e. chlorophyll concentration) (Jacobsen et al. 2018). In addition, cod 0-group indices, which are based on the June survey, closely resemble the local primary production index (Jacobsen et al. 2019). Together, these observations suggest that sub optimal feeding conditions during the late larval period may be a main critical phase for survival to the end of the pelagic stage in Faroe Plateau cod.

\section{The early juvenile period}

In terms of relative importance, late stage $C$. finmarchicus dominated the diet of early juvenile cod (Fig. 6e). Late stage C. finmarchicus were also the most preferred prey during the early juvenile period (Fig. 9i) supporting the hypothesis that C. finmarchicus is a key prey item for early pelagic juvenile cod in most areas in the North Atlantic (Heath and Lough 2007 and references there in).

There was, however, a discrepancy between the mean size of prey ingested compared with the preferred size of prey ingested by early juvenile cod (Fig. 8a). Early juvenile cod generally ingested smaller prey than what they prefer indicating once again that there may be a low abundance of preferred sized prey for early pelagic juveniles. The Faroe shelf summer zooplankton community generally shifts between being dominated by $C$. finmarchicus and dominated by smaller, neritic copepods i.e. T. longicornis and Acartia sp. (Gaard 1999, 2003). The neritic copepods are more abundant in years with high primary production (Jacobsen et al. 2018), while the summer abundance of $C$. finmarchicus is related to inter-annual differences in predation pressure from 0-group fish e.g. cod (Jacobsen et al. 2019), the variable exchange rate between on- and offshelf waters (Gaard and Hansen 2000) as well as the general production in the open ocean and on the shelf (Gaard 2000). Thus the difference in the mean size of prey ingested compared with the preferred size of prey ingested by early juvenile cod is most likely caused by a combination of high abundance of small prey together with a low abundance of preferred sized prey depending on the contemporary environmental conditions. This complies with a parallel study by Jacobsen (in preparation) investigating inter-annual differences in the feeding of pelagic Faroe Plateau cod. The study shows that the abundance of late stage $C$. finmarchicus in early juvenile cod is lower in years with high primary production than in years with low primary production. While late stage $C$. finmarchicus was the 
most preferred species in early juveniles, the neritic copepod $T$. longicornis was the most abundant prey species at this particular development stage (Fig. 6b, c). In addition, $T$. longicornis appeared relatively important for cod juveniles (Fig. 6e), and thus this species is likely a good supplement to the cod diet when food is sparse.

\section{The late juvenile period}

Decapod larvae were the most important food item for late juvenile cod (Fig. 6e). Most other studies report euphausiids/mysids as the main prey for the largest pelagic juvenile cod (Heath and Lough 2007). However, in this study, only a total of 33 euphausiids were found in all of the stomachs (i.e. $1.4 \%$ of the total dry weight in the group malacostraca), most likely because euphausiids are not abundant on the shelf. Instead, meroplanktonic decapod zoeae appear to be very important in the feeding ecology of cod juveniles on the Faroe shelf (Fig. 7j). In addition, fish, primarily gadoids, were present in the guts of late juvenile cod. Thus, cannibalism in cod may start already at this early life stage potentially regulating the recruitment. Cannibalism is likely more severe when other prey species are limited.

\section{Conclusion}

Larval and pelagic juvenile Faroe Plateau cod (Gadus morhua) generally show the same feeding patterns as other North Atlantic cod stocks with high selectivity towards some prey species while avoiding others. Copepod (most likely $C$. finmarchicus) eggs are particularly important for early stage larvae followed by calanoid nauplii. At the late larval stage copepods of the genera Acartia and Pseudocalanus appear to be of particular importance and the feeding conditions at this stage may be the most critical for successful cod larval development and endurance. In the early juvenile period late stage $C$. finmarchicus copepodites are clearly the most favoured prey, while decapod larvae are the most preferred prey for late juveniles. However, since the gut content at any point in time most likely is affected by the contemporary prey availability and since the Faroe shelf prey availability is highly variable between years, a study investigating interannual differences in feeding is warranted. Furthermore, the possibility that it is a lack of suitable prey during the late larval period of cod that is most critical for survival to the end of the pelagic stage also calls for further exploration, and we recommend that future studies focus more on the period when late larvae are most abundant i.e. mid May.
Acknowledgements We thank Hjálmar Hátún for constructive discussions during the writing process. We are also grateful for the constructive comments made by the independent reviewers.

Author contributions This study was designed by KKN, RK, PG, EG and PS, the field work was carried out by EG, the data analysis was conducted by SJ, the story was composed by SJ with contribution from $\mathrm{KKN}, \mathrm{RK}, \mathrm{PG}, \mathrm{EG}$ and PS, and SJ led the writing process.

Funding The making of this paper has been funded by STATOIL Faroes and the Faroese Research Council (Grant number 0443).

\section{Compliance with ethical standards}

Conflict of interest The authors declare that they have no conflict of interest.

Ethic approval The authors declare that all applicable national and institutional guidelines for sampling, care and experimental use of organisms for the study have been followed and all necessary approvals were obtained.

Data availability The datasets generated during and/or analysed during the current study are available from the corresponding author on reasonable request.

Open Access This article is licensed under a Creative Commons Attribution 4.0 International License, which permits use, sharing, adaptation, distribution and reproduction in any medium or format, as long as you give appropriate credit to the original author(s) and the source, provide a link to the Creative Commons licence, and indicate if changes were made. The images or other third party material in this article are included in the article's Creative Commons licence, unless indicated otherwise in a credit line to the material. If material is not included in the article's Creative Commons licence and your intended use is not permitted by statutory regulation or exceeds the permitted use, you will need to obtain permission directly from the copyright holder. To view a copy of this licence, visit http://creativecommons.org/licenses/by/4.0/.

\section{References}

Anderson JT (1988) A review of size dependant survival during prerecruit stages of fishes in relation to recruitment. J Northwest Atl Fish Sci 8:55-66. https://doi.org/10.2960/J.v8.a6

Beaugrand G, Brander KM, Lindley JA, Souissi S, Reid PC (2003) Plankton effect on cod recruitment in the North Sea. Nature 426:661-664. https://doi.org/10.1038/nature02164

Buckley LJ, Durbin EG (2006) Seasonal and inter-annual trends in the zooplankton prey and growth rate of Atlantic cod (Gadus morhua) and haddock (Melanogrammus aeglefinus) larvae on Georges Bank. Deep Sea Res II Top Stud Oceanogr 53:27582770. https://doi.org/10.1016/j.dsr2.2006.08.009

Castellani C, Edwards M (2017) Marine Plankton: a practical guide to ecology, methodology, and taxonomy. Oxford University Press, Oxford. https://doi.org/10.1093/acprof:oso/9780199233 267.001.0001

Chesson J (1978) Measuring preference in selective predation. Ecology 59:211-215

Chesson J (1983) The estimation and analysis of preference and its relationship to foraging models. Ecology 64:1297-1304 
Conway DVP (2006) Identification of the copepodite developmental stages of twenty-six North Atlantic copepods, vol 21, revised edn. Marine Biological Association of the United Kingdom Occasional Publications, Plymouth. https://doi.org/10.13140 /2.1.5043.8089

Cushing DH (1990) Plankton production and year-class strength in fish populations: an update of the match/mismatch hypothesis. Adv Mar Biol 26:249-293

Debes HH, Eliasen K (2006) Seasonal abundance, reproduction and development of four key copepod species on the Faroe shelf. Mar Biol Res 2:249-259. https://doi.org/10.1080/17451000600798787

Debes H, Eliasen K, Gaard E (2008a) Seasonal variability in copepod ingestion and egg production on the Faroe shelf. Hydrobiologia 600:247-265. https://doi.org/10.1007/s10750-007-9238-3

Debes HH, Gaard E, Hansen B (2008b) Primary production on the Faroe shelf: temporal variability and environmental influences. J Mar Syst 74:686-697. https://doi.org/10.1016/j.jmars ys.2008.07.004

Eliasen SK, Hátún H, Larsen KMH, Hansen B, Rasmussen TAS (2017) Phenologically distinct phytoplankton regions on the Faroe Shelf_-identified by satellite data, in situ observations and model. J Mar Syst 169:99-110. https://doi.org/10.1016/j. jmarsys.2017.01.015

Folkvord A, Øiestad V, Kvenseth PG (1994) Growth patterns of three cohorts of Atlantic cod larvae (Gadus morhua L.) studied in a macrocosm. ICES J Mar Sci 51:325-336

Fossum P, Ellertsen B (1994) Gut content analysis of first-feeding cod larvae (Gadus morhua L.) sampled at Lofoten, Norway, 1979_ 1986. ICES Mar Sci Symp 198:430-437

Gaard E (1999) The zooplankton community structure in relation to its biological and physical environment on the Faroe shelf, 19891997. J Plankton Res 21:1133-1152. https://doi.org/10.1093/plank $\mathrm{t} / 21.6 .1133$

Gaard E (2000) Seasonal abundance and development of Calanus finmarchicus in relation to phytoplankton and hydrography on the Faroe Shelf. ICES J Mar Sci 57:1605-1611. https://doi. org/10.1006/jmsc.2000.0963

Gaard E (2003) Plankton variability on the Faroe Shelf during the 1990s. ICES Mar Sci Symp 219:182-189

Gaard E, Hansen B (2000) Variations in the advection of Calanus finmarchicus onto the Faroe Shelf. ICES J Mar Sci 57:1612-1618. https://doi.org/10.1006/jmsc.2000.0962

Gaard E, Reinert J (2002) Pelagic cod and haddock juveniles on the Faroe plateau: distribution, diets and feeding habitats, 1994-1996. Sarsia 87:193-206. https://doi.org/10.1080/00364820260294833

Gaard E, Steingrund P (2001) Reproduction of Faroe Plateau cod: spawning grounds, egg advection and larval feeding. Fróðskaparrit 48:87-103

Hay SJ, Kiørboe T, Matthews A (1991) Zooplankton biomass and production in the North Sea during the Autumn Circulation experiment, October 1987-March 1988. Cont Shelf Res 11:1453-1476. https://doi.org/10.1016/0278-4343(91)90021-W

Heath MR, Lough RG (2007) A synthesis of large-scale patterns in the planktonic prey of larval and juvenile cod (Gadus morhua). Fish Oceanogr 16:169-185. https://doi.org/10.111 1/j.1365-2419.2006.00423.x

Hirche HJ, Brey T, Niehoff B (2001) A high-frequency time series at Ocean Weather Ship Station M (Norwegian Sea): population dynamics of Calanus finmarchicus. Mar Ecol Prog Ser 219:205219. https://doi.org/10.3354/meps219205

Hjort J (1914) Fluctuations in the great fisheries of northern Europe viewed in the light of biological research. Rapp P V Réun Cons Int Explor Mer 20:228

Hygum BH, Rey C, Hansen BW, Tande K (2000) Importance of food quantity to structural growth rate and neutral lipid reserves accumulated in Calanus finmarchicus. Mar Biol 136:1057-1073. https://doi.org/10.1007/s002270000292

Jacobsen S, Gaard E, Larsen KMH, Eliasen SK, Hátún H (2018) Temporal and spatial variability of zooplankton on the Faroe shelf in spring 1997-2016. J Mar Syst 177:28-38. https://doi. org/10.1016/j.jmarsys.2017.08.004

Jacobsen S, Gaard E, Hátún H, Steingrund P, Larsen KMH, Reinert J, Ólafsdóttir SR, Poulsen M, Vang HBM (2019) Environmentally driven ecological fluctuations on the Faroe Shelf revealed by fish juvenile surveys. Front Mar Sci 6:1-12. https://doi.org/10.3389/ fmars.2019.00559

Jákupsstovu SHÍ, Reinert J (1994) Fluctuations in the Faroe Plateau cod stock. ICES Mar Sci Symp 198:194-211

Jónasdóttir SH, Richardson K, Heath MR, Ingvarsdóttir A, Christoffersen A (2008) Spring production of Calanus finmarchicus at the Iceland-Scotland Ridge. Deep Sea Res I Oceanogr Res Pap 55:471-489. https://doi.org/10.1016/j.dsr.2007.12.009

Jung-Madsen S, Nielsen TG, Grønkjær P, Hansen BW, Møller EF (2013) Early development of Calanus hyperboreus nauplii: response to a changing ocean. Limnol Oceanogr 58:2109-2121. https://doi.org/10.4319/lo.2013.58.6.2109

Kane J (1984) The feeding habits of co-occurring cod and haddock larvae from Georges Bank. Mar Ecol Prog Ser 16:9-20. https:// doi.org/10.3354/meps016009

Kattner G, Krause M (1987) Changes in lipids during the development of Calanus finmarchicus s.l. from Copepodid I to adult. Mar Biol 96:511-518. https://doi.org/10.1007/BF00397968

Larsen KMH, Hansen B, Svendsen H (2008) Faroe Shelf water. Cont Shelf Res 28:1754-1768. https://doi.org/10.1016/j. csr.2008.04.006

Larsen KMH, Hansen B, Svendsen H (2009) The Faroe Shelf Front: properties and exchange. J Mar Sys 78:9-17. https://doi. org/10.1016/j.jmarsys.2009.02.003

Leggett WC, Deblois E (1994) Recruitment in marine fishes: is it regulated by starvation and predation in the egg and larval stages? Neth J Sea Res 32:119-134. https://doi.org/10.1016/00777579(94)90036-1

Lindley JA (1988) Estimating biomass and production of pelagic larvae of brachyuran decapods in western European shelf waters. J Exp Mar Biol Ecol 122:195-211

Madsen ML, Gaard E, Hansen BW (2008) Wax-ester mobilization by female Calanus finmarchicus (Gunnerus) during spring ascendance and advection to the Faroe Shelf. ICES J Mar Sci 65:1112_ 1121. https://doi.org/10.1093/icesjms/fsn097

McLaren IA, Avendaño P (2011) Prey field and diet of larval cod on Western Bank, Scotian Shelf. Can J Fish Aquat Sci 52:448-463. https://doi.org/10.1139/f95-046a

McLaren IA, Avendaño P, Taggart CT, Lochmann SE (1997) Feeding by larval cod in different water-masses on Western Bank, Scotian Shelf. Fish Oceanogr 6:250-265. https://doi.org/10.104 6/j.1365-2419.1998.00044.x

Munk P (1997) Prey size spectra and prey availability of larval and small juvenile cod. J Fish Biol 51:340-351. https://doi. org/10.1111/j.1095-8649.1997.tb06107.x

Munk P, Nielsen JG (2005) Eggs and larvae of north sea fishes. Biofolia, Frederiksberg, p 215

Nichols JH, Thompson AB (1991) Mesh selection of copepodite and nauplius stages of four calanoid copepod species. J Plankton Res 13:661-671. https://doi.org/10.1093/plankt/13.3.661

Overton JL, Meyer S, Støttrup JG, Peck MA (2010) Role of heterotrophic protists in first feeding by cod (Gadus morhua) larvae. Mar Ecol Prog Ser 410:197-204. https://doi.org/10.3354/meps08658

Pante E, Simon-Bouhet B (2013) marmap: A package for importing, plotting and analyzing bathymetric and topographic data in R. PLoS ONE 8(9):e73051. https://doi.org/10.1371/journ al.pone. 0073051 
Pepin P, Penney RW (1997) Patterns of prey size and taxonomic composition in larval fish: are there general size-dependent models? J Fish Biol 51:84-100. https://doi.org/10.1111/j.1095-8649.1997. tb06094.x

Pinkas L, Oliphante MS, Iverson ILK (1971) Food habits of albacore, bluefin tuna and bonito in California waters. Calif Fish Game 152:1-105

Richardson K, Jónasdóttir SH, Hay SJ, Christoffersen A (1999) Calanus finmarchicus egg production and food availability in the Faroe-Shetland Channel and northern North Sea: October-March. Fish Oceanogr 8:153-162. https://doi.org/10.104 6/j.1365-2419.1999.00007.x

Robert D, Levesque K, Gagné JA, Fortier L (2011) Change in prey selectivity during the larval life of Atlantic cod in the southern Gulf of St Lawrence. J Plankton Res 33:195-200. https://doi. org/10.1093/plankt/fbq095

Rowlands WL, Dickey-Collas M, Geffen AJ, Nash RDM (2006) Gape morphology of cod Gadus morhua L., haddock Melanogrammus aeglefinus (L.) and whiting Merlangius merlangus (L.) through metamorphosis from larvae to juveniles in the western Irish Sea. J Fish Biol. https://doi.org/10.1111/j.1095-8649.2006.01200.x

Rowlands WL, Dickey-Collas M, Geffen AJ, Nash RDM (2008) Diet overlap and prey selection through metamorphosis in Irish Sea cod (Gadus morhua), haddock (Melanogrammus aeglefinus), and whiting (Merlangius merlangus). Can J Fish Aquat Sci 65:12971306. https://doi.org/10.1139/F08-041

Seljeset O, Vollset KW, Folkvord A, Geffen AJ (2010) The role of prey concentration and size range in the growth and survival of larval cod. Mar Biol Res 6:251-262. https://doi.org/10.1080/17451 000903150355

Steingrund P, Mouritsen R, Reinert J, Gaard E, Hátún H (2010) Total stock size and cannibalism regulate recruitment in cod (Gadus morhua) on the Faroe Plateau. ICES J Mar Sci 67:111-124. https ://doi.org/10.1093/icesjms/fsp240

Stenevik EK, Melle W, Gaard E, Gislason A, Broms CT, Prokopchuk I, Ellertsen B (2007) Egg production of Calanus finmarchicus-a basin-scale study. Deep Sea Res II Top Stud Oceanogr 54:26722685. https://doi.org/10.1016/j.dsr2.2007.08.027
Svetlichny LS, Kideys AE, Hubareva ES, Besiktepe S, Isinibilir M (2006) Development and lipid storage in Calanus euxinus from the Black and Marmara seas: variabilities due to habitat conditions. J Mar Syst 59:52-62. https://doi.org/10.1016/j.jmars ys.2005.09.003

Swalethorp R, Kjellerup S, Malanski E, Munk P, Nielsen TG (2014) Feeding opportunities of larval and juvenile cod (Gadus morhua) in a Greenlandic fjord: temporal and spatial linkages between cod and their preferred prey. Mar Biol 161:2831-2846. https://doi. org/10.1007/s00227-014-2549-9

Swalethorp R, Malanski E, Dalgaardagersted M, Nielsen TG, Munk P (2015) Structuring of zooplankton and fish larvae assemblages in a freshwater influenced Greenlandic fjord: influence from hydrography and prey availability. J Plankton Res 37:102-119. https:// doi.org/10.1093/plankt/fbu099

R Core Team (2018) R: a language and environment for statistical computing. R Foundation for Statistical Computing, Vienna. R version 3.5.2. http://www.R-project.org/. Accessed 20 Dec 2018

Thompson AB, Harrop RT (1991) Feeding dynamics of fish larvae on Copepoda in the western Irish Sea, with particular reference to cod Gadus morhua. Mar Ecol Prog Ser 68:213-223

Thorisson K (1989) The food of larvae and pelagic juveniles of cod (Gadus morhua L.) in the coastal waters west of Iceland. Rapp P V Réun Cons Int Explor Mer 191:264-272

Uye S (1982) Length-weight relationships of important zooplankton from the Inland Sea of Japan. J Oceanogr Soc Jpn 38:149-158. https://doi.org/10.1007/BF02110286

van der Meeren T, Næss T (1993) How does cod (Gadus morhua) cope with variability in feeding conditions during early larval stages? Mar Biol 116:637-647. https://doi.org/10.1007/BF00355482

Publisher's Note Springer Nature remains neutral with regard to jurisdictional claims in published maps and institutional affiliations. 